ISSN 1991-8631

Original Paper

http://indexmedicus.afro.who.int

\title{
Perceptions of the use of indigenous leaves as packaging materials in the ready-to-eat cornmeals
}

\author{
J.K. MENSAH ${ }^{1 *}$, E. ADEI $^{1}$, D. ADEI ${ }^{2}$ and M. D. ASHIE ${ }^{1}$ \\ ${ }^{I}$ Department of Chemistry, Kwame Nkrumah Universioty of Science and Technology. Kumasi, Ghana. \\ ${ }^{2}$ Department of Planning, Kwame Nkrumah Universioty of Science and Technology.Kumasi, Ghana. \\ "Corresponding author,E-mail:jkmensah.cos@knust.edu.gh ; eadei@yahoo.com; ladydeeust@yahoo.com; \\ mosiatmosat@yahoo.com
}

\begin{abstract}
Although alternative food packaging materials are available, Ghanaians still use leaves to package some ready-to-eat cornmeal products. This study examines the perceptions of a representative community sample of 70 producers, 40 sellers and 120 consumers of ready-to-eat leaves-packaged cornmeal products in Kumasi using questionnaires. Fante Kenkey (packaged in dried leaves of either musa paradisiaca or sterculia tragacanta) and Ga kenkey (packaged in dried sheaths of zea mays) are the most preferred products, accounting together for $80 \%$ of all leaves-packaged cornmeals processed by producers, for $76 \%$ of products offered by sellers and for $96 \%$ of products purchased by consumers. Reasons producers cited for the continued utilization of leaves as packaging materials include medicinal via the infusion of the cornmeal with beneficial phytonutrients that also imparts distinctive aroma and taste (61\%), environmental friendliness (17\%), availability (4\%), relatively low cost (4\%), lack of toxicity and renewability (14\%). Despite consumers concerns of unhygienic (7\%), short shelf lives (18\%) and loss of moisture leading to hardening of Ga Kenkey (60\%), $87 \%$ of consumers declined a suggestion for use of alternative packaging materials for ready-to-eat cornmeals. Data provided by this study can be used to examine food packaging trends for research and policy analyses in Ghana.

(C) 2012 International Formulae Group. All rights reserved.
\end{abstract}

Keywords: Kenkey, musa paradisiaca, sterculia tragacanta, zea mays, phytochemical, leaf-package.

\section{INTRODUCTION}

Food packaging has emerged as a key factor that determines consumer's dietary behavior (Rettie and Brewer, 2000). The earliest food packaging materials were probably leaves from higher plants (Risch, 2009) but over the centuries, food packaging materials has undergone considerable revolution in moving away from natural materials such as leaves to synthetic organic materials such as polyethylene (Brody et al., 2008). Food marketers frequently target specific consumers with dynamic packaging attributes designed specifically to promote consumer purchases of their branded food products (Nancarrow et al., 1998). The fluidity of consumer preferences and the complexity of food packaging techniques today undoubtedly suggest that leavespackaged food items will have little appeal to 
consumer taste in modern society (Silayoi and Speece, 2007; Imran et al., 2010).

Yet the use of leaves to package cornmeal products in Ghana has enjoyed continuing marketing success without changes (Dainelli et al., 2008). Ghana relies heavily on corn as dietary staple and different forms of fermented and unfermented corn meals have historically been offered to consumers as leaves-packaged ready-to-eat items. These cornmeals include Fante Kenkey (Ntaw) (packaged in dried leaves of musa paradisiaca), Fante Kenkey (Dokon Pa) (packaged in dried leaves of sterculia tragacanta), Ga kenkey (packaged in dried sheaths of zea mays), Fomfom (packaged in fresh toasted leaves of musa paradisiaca), Nsiho (packaged in fresh leaves of musa paradisiaca), Estwe (packaged in dried leaves of musa paradisiaca), Kaafa (packaged in fresh leaves of thespesia populnea), Nkyekyera (packaged in dried sheaths of zea mays or in fresh leaves of thespesia populnea), Aboloo (packaged in fresh leaves of thespesia populnea), Sugared Kenkey (packaged in dried leaves of musa paradisiaca) and Osino graphic (packaged in dried leaves of marantochloa cuspidata) (Amoa and Muller, 1976). The use of leaves as cornmeal wrappers is not restricted to rural communities but found in urban communities as well.

But the traditional practice of packaging cornmeal with leaves in Ghana suffers major information gaps. While neither the offering of these products nor the consumption has ever been an issue, it is nevertheless the case that relatively little is known about leaves-packaged cornmeals. Questions regarding the reasons for the continuing usage of leaves in spite of the availability of plastic-based food packaging materials linger. Other questions including consumer demand for leaves-packaged cornmeal, the shelf-lives of the products, the identity of phytochemicals that leach into the product and the involvement of these phytochemicals in the health-related consequences of leaves-packaged cornmeal ingestion are yet to be clearly answered. Additionally, little information exists on the demographics and the perceptions of the producers, the sellers and the consumers of leaves-packaged cornmeals.

With continued consumption of leavespackaged cornmeal in Ghana, an urgent need exists for population-based surveys that address the prevalence of this practice as well as fill-in the existing information gaps. Data from such population-based surveys will ultimately enrich public policy discussions regarding optimal approaches to improving food quality in Ghana. This study evaluates the demographic patterns of producers, sellers and consumers of leaves-packaged cornmeals in Kumasi in Ghana and examines the perceived underlying reasons for the prevalence of leaves-packaged cornmeal products in Ghana.

\section{MATERIALS AND METHODS}

\section{Survey method}

The research used a cross-sectional approach where variables of interest in a sample of subjects were examined and the relationships between them determined. It specifically used case study design because a contemporary phenomenon based on a real life situation was studied. The study relied on primary and secondary data source, and adopted a procedure involving collecting data and information on: type of product processed sold or consumed; preference of leaves to alternative packaging materials; perceived consumer demand for the product; knowledge of potential medicinal value of the leaves used for packaging corn meals; perceived positive or negative health effects experienced after ingestion of leaves-packaged food and whether or not the specific health effect is attributable to the leaves packaging. Data from primary source were collected based on structured questionnaires, observation and interviews while secondary data were obtained from journals, World Wide Web and other relevant literature materials. The 
research was conducted from September 2007 to March 2008.

\section{Survey area and sample size}

Since a sample frame was not readily available, a recognisance survey was conducted and the study focused on areas (Dakojom, Susanso, Ayigya, Kejetia, Race Course and Central Market) predominately noted for production and retailing of ready-toeat leaves-packaged cornmeal products in Kumasi Metropolitan area. After explaining the purpose of the study to Producers and retailers, those who gave consent were administered with questionnaires at their own convenience to reduce the non-response rate. Consented consumers of the products at the retail joints were also administered with questionnaires. A sample size of 230 was chosen: 70 producers, 40 retailers and 120 consumers. After pre-testing of the questionnaires, they were administered with closed ended questionnaire. The questionnaires were prepared in English, but local language, Twi was used to translate and communicate the content of the questionnaire where necessary since $80 \%$ of the producers and retailers were more comfortable with the local language. Since the mother tongue of the researchers who administered the questionnaires is Twi, the questionnaire could easily be interpreted.

\section{Statistical analysis}

The nature of the research necessitated a combination of both qualitative and quantitative techniques to analyse the data. The questionnaires were analyzed using Statistical Package for Social Science (SPSS) software (SPSS-PC for windows, version 16). In analyzing the data, statistical association was used to establish relationships and tables, graphs and appropriate illustrations were used.

\section{RESULTS}

Eleven available leaves-packaged cornmeals were identified in the market. As shown in Table 1, the cornmeals include Fante
Kenkey (Ntaw), Fante Kenkey (Dokon Pa), Ga Kenkey, Fomfom, Nsiho, Estew, Kaafa, Nkyekyera, Aboloo, Sugared Kenkey, and Osino graphic. Figure 1 (a-f) presents pictures of some cornmeal products sampled in the study area.

Demand for available products varied substantially. Fante and Ga Kenkeys were on the high end of the demand spectrum with $86 \%$ and $74 \%$ high demands respectively (Table 2). Kaafa was considered an average demand item by $80 \%$ consumers while sugared Kenkey was evenly split between average $(50 \%)$ and low $(50 \%)$ demands.

When completed questionnaires were examined for demographics, all 70 interviewed producers (Table 3 ) were found to be females with $56 \%$ of them above 46 years. Most producers were married (86\%). Producers have relatively low education with $50 \%$ having no formal education, and $44 \%$ having primary/middle school education. Most of the producers ( $94 \%$ ) have been on the job for more than 5 years; $38 \%$ have been employed as producers for more than 21 years. The prevalent products processed are Fante Kenkey (41\%) and Ga Kenkey (39\%).

All 40 sellers (Table 4) were females with $38 \%$ of them aged $26-35$ years. The highest proportion (63\%) was married. Sellers' level of education were relatively low with $43 \%$ having no formal education, $37 \%$ with primary/middle school, $10 \%$ with secondary and $10 \%$ with technical/vocational. None of the sellers had tertiary education. Most of the sellers offered Fante Kenkey (53\%) and Ga Kenkey (23\%) with $40 \%$ of them selling more than 150 balls of each item per day.

The 120 consumers (Table 5) comprised $91(76 \%)$ males and $29(24 \%)$ females mostly 25 years or younger $(81 \%)$. Consumers were relatively highly educated with $83 \%$ tertiary trained, $6 \%$ secondary, $8 \%$ primary/middle, and $3 \%$ no formal education. Perhaps the large number of tertiary trained consumers is a reflection of the sampling areas close proximity to the Kwame Nkrumah 
University of Science and Technology. The most prevalent leaf-packaged product purchased is Ga Kenkey (54\%) followed closely by Fante Kenkey (46\%). Most consumers have eaten 2 balls $(66 \%)$ of either $\mathrm{Ga}$ or Fante Kenkey three times in a week $(56 \%)$ for $11-20$ years $(46 \%)$. The high consumer demand for Fante and Ga Kenkey correlated with prevalent products made by producers (Table 3) and offered by sellers (Table 4).

Since demographics alone may not fully explain the continuing use of leaves as packaging materials, completed questionnaires for producers were assessed for reason for the prevalence of leaves as cornmeal packaging material. Reasons producers cited for the continued utilization of leaves as packaging materials include medicinal via the infusion of the cornmeal with beneficial phytonutrients that also provides distinctive aroma and taste $(61 \%)$, biodegradability (17\%), availability $(4 \%)$ at relatively low cost (4\%) and others (14\%) (Figure 2). Reasons categorized as "others" encompass producers' perceived lack of toxicity, renewability and personal preferences.

Because medicinal was the predominant reason for producer preference of leaves in packaging cornmeals, producer completed questionnaires were further examined for ethnomedicinal usage of any form of any of the leaves-packaged cornmeals. As shown in Figure 3, unanimous agreement was obtained from all producers that the residual liquid obtained from boiling Ga Kenkey has three ethnomedicinal uses: curing fever $(61 \%)$ and abdominal pains $(25 \%)$ and used as purgative $(7 \%)$.

Yet when consumer knowledge of the type and nature of chemical compounds that might leach into the cornmeals were examined, a majority (62\%) has no idea of the identity of the potential phytochemicals that might "migrate" from leaves to cornmeals (Figure 4). Without providing chemical names or classifications, $18 \%$ cited coloured dyes as possible "migrants" from leaves to cornmeal. Only $2 \%$ consumers stated alkaloids as potential leaves phyto-constitutents likely to leach into the cornmeal. A $10 \%$ stated microbial transfer from leaves to the cornmeal as a possibility. A further $8 \%$ noted other reasons including the likelihood for unknown poisonous substances in the leaves leaching into the cornmeal.

As anticipated, most producers (59\%) have no apparent concerns over the use of leaves to package cornmeals (Table 6). Most sellers' (47\%) and consumers' (60\%) concerns focused on how easy it is for $\mathrm{Ga}$ Kenkey to harden following loss of moisture. No related concerns on moisture content for Fante Kenkey were raised. The low shelf lives of the products were the next line of concern for the sellers $(20 \%)$ and consumers $(18 \%)$ but not the producers (6\%). Producers (19\%) placed more emphasis on other reasons than sellers $(8 \%)$ and consumers $(5 \%)$. The other reasons comprise personal preferences. None of the sellers perceived the products to be unhygienic. The perceived unhygienic nature of the products was also the least area of concern for producers (5\%) and the fourth area of concern for consumers $(7 \%)$.

When the perceived shelf lives of Fante and Ga Kenkeys were assessed via consumer completed questionnaire (Figure 5), 69\% consumers specified that Fante Kenkey has a shelf life of 6-10 days while $81 \%$ indicated that the shelf life of Ga Kenkey was 2-5 days. The shelf lives of the less popular cornmeal products were not examined.

Given consumers' concerns (Table 6), completed questionnaires were examined for possible consumer desire for change from leaves to alternative packaging materials for cornmeal. An overwhelming $87 \%$ disagreed to the use of alternative material (Figure 6). The $13 \%$ of consumers that were in agreement, however, lamented the likely loss of the unique taste and aroma of the cornmeal if a switch is made from leaves to other packaging materials such as polyethylene. 
J.K. MENSAH et al. / Int. J. Biol. Chem. Sci. 6(3): 1051-1068, 2012

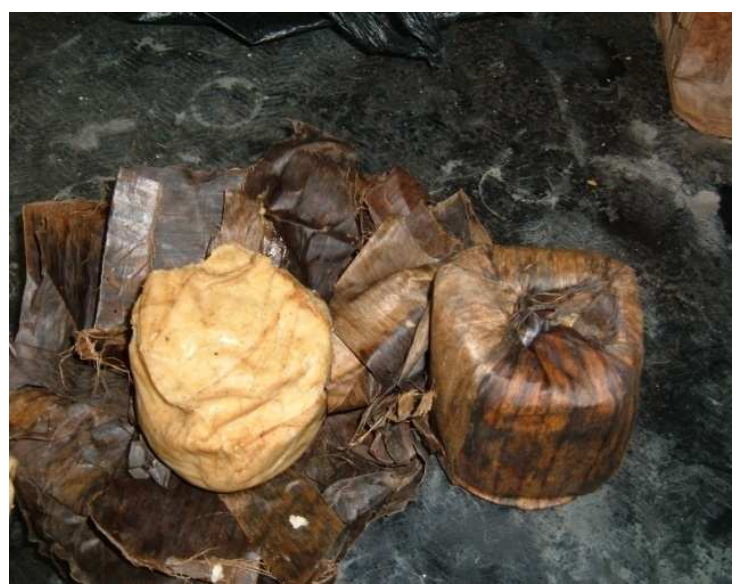

(a)

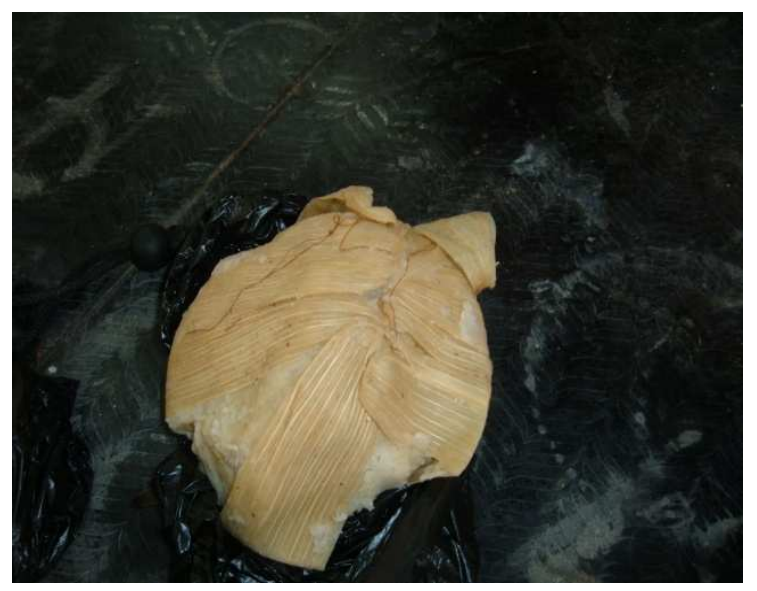

(b)

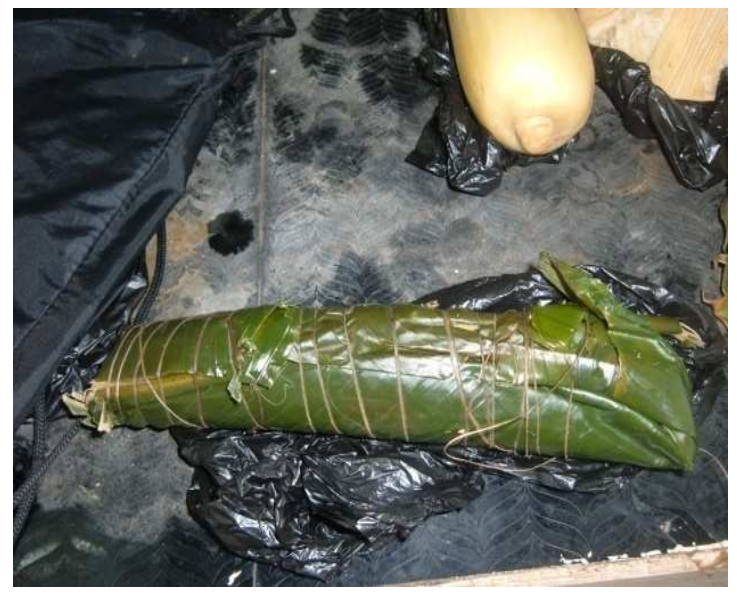

(c) 
J.K. MENSAH et al. / Int. J. Biol. Chem. Sci. 6(3): 1051-1068, 2012

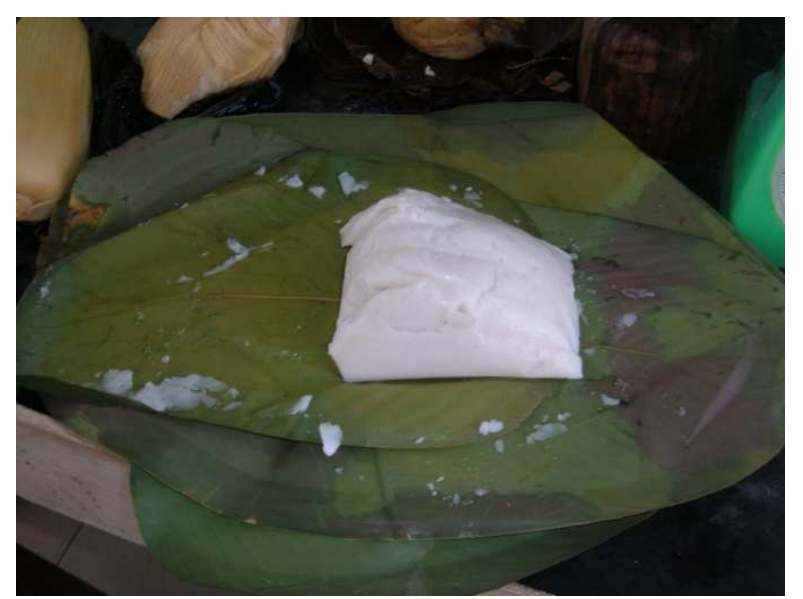

(d)

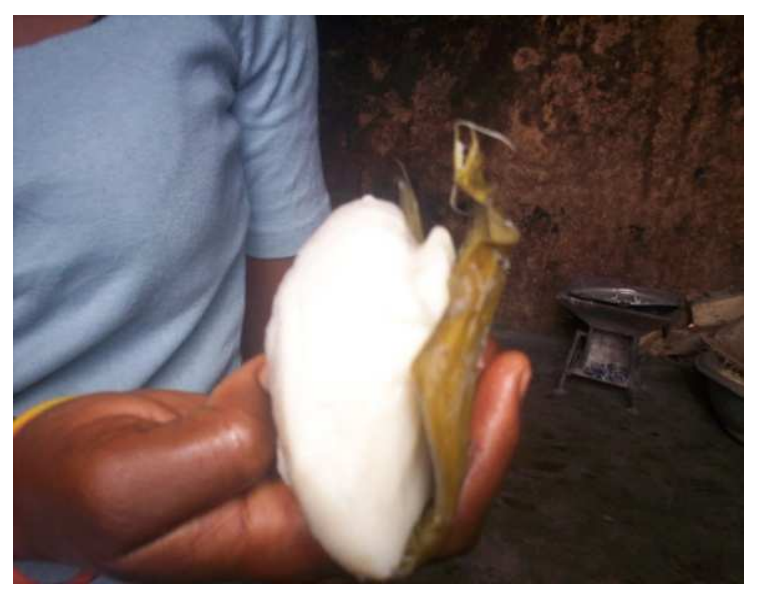

(e)

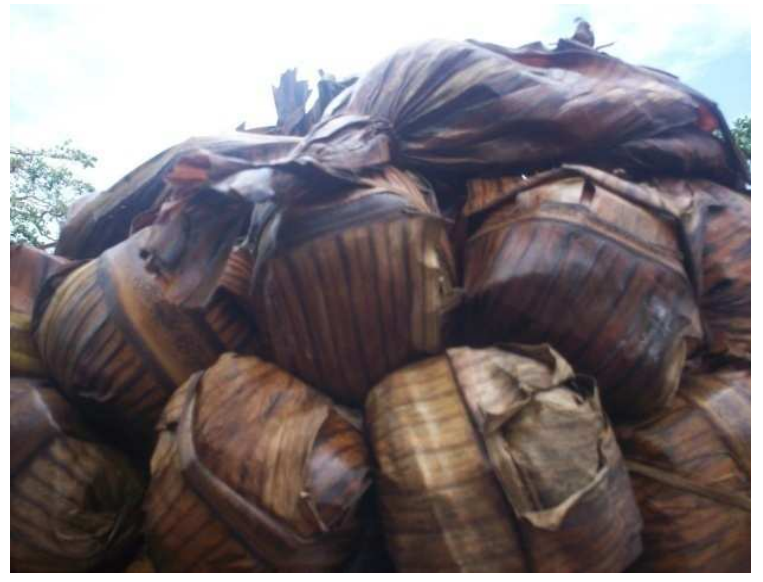

(f)

Figure 1: Leaves-packaged cornmeals sampled in the market include: (a) zea mays sheath- packaged Ga Kenkey, (b) peeled musa paradisiaca-packaged Fante Kenkey, (c) thespesia populnea-packaged Nkyekyere, (d) peeled thespesia populnea-packaged Kaafa, (e) peeled zea mays sheath-packaged Aboloo and (f) musa paradisciaca-packaged sugared Kenkey. 


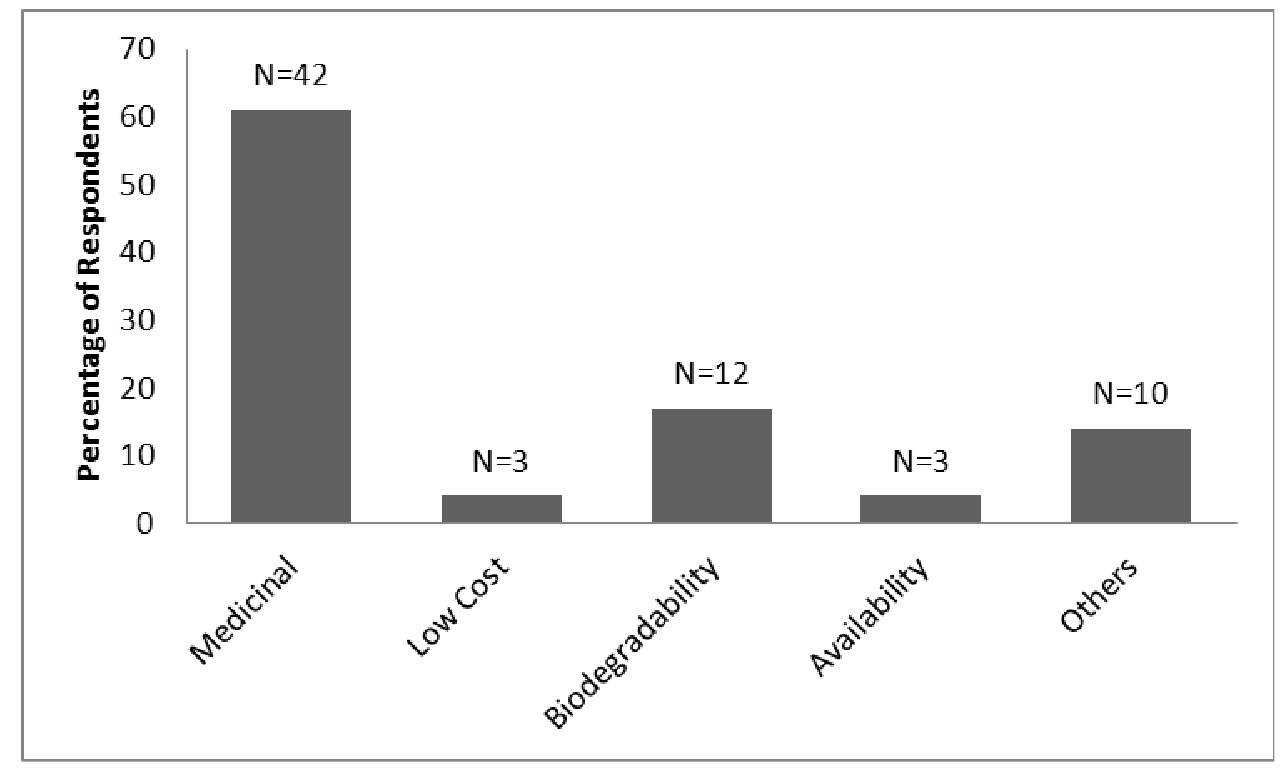

Figure 2: Producers reasons for the prevalence of leaves as packaging materials for cornmeals.

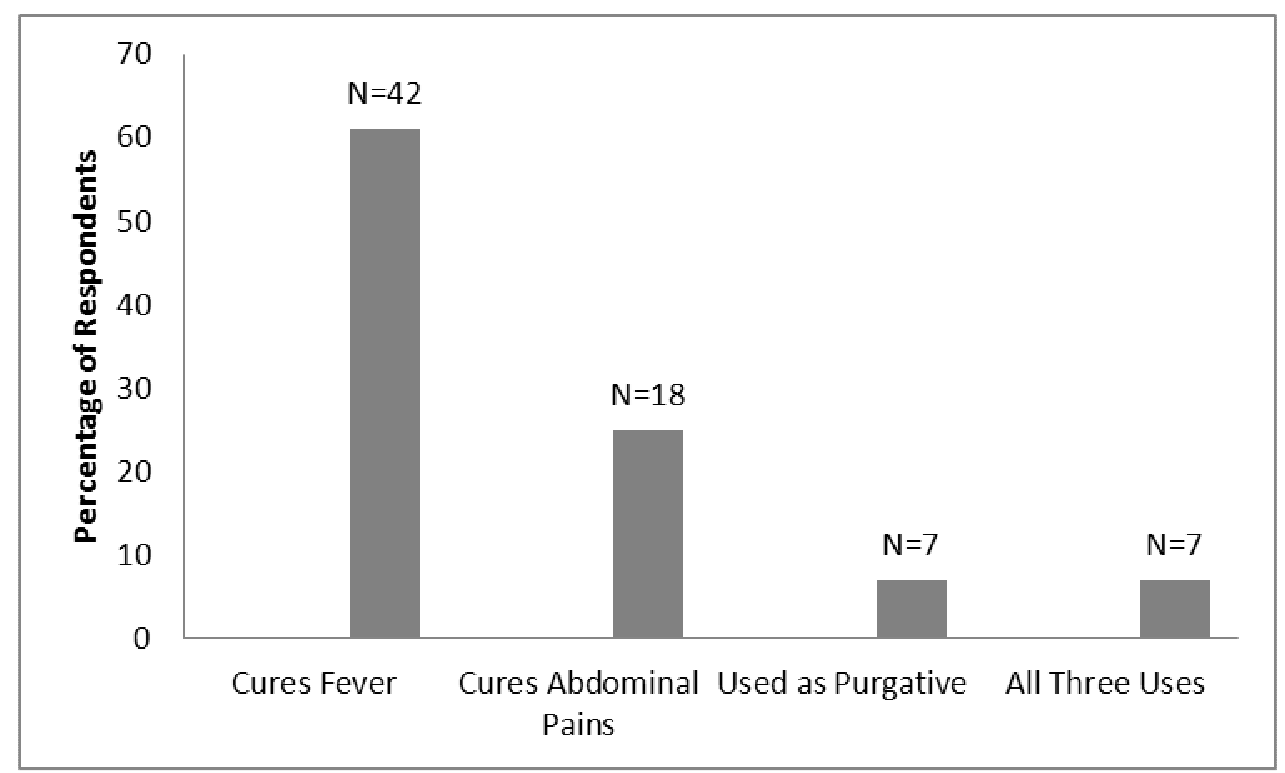

Figure 3: Producers assessment of ethnomedicinal use of residual liquid from leaves-packaged cornmeals. 


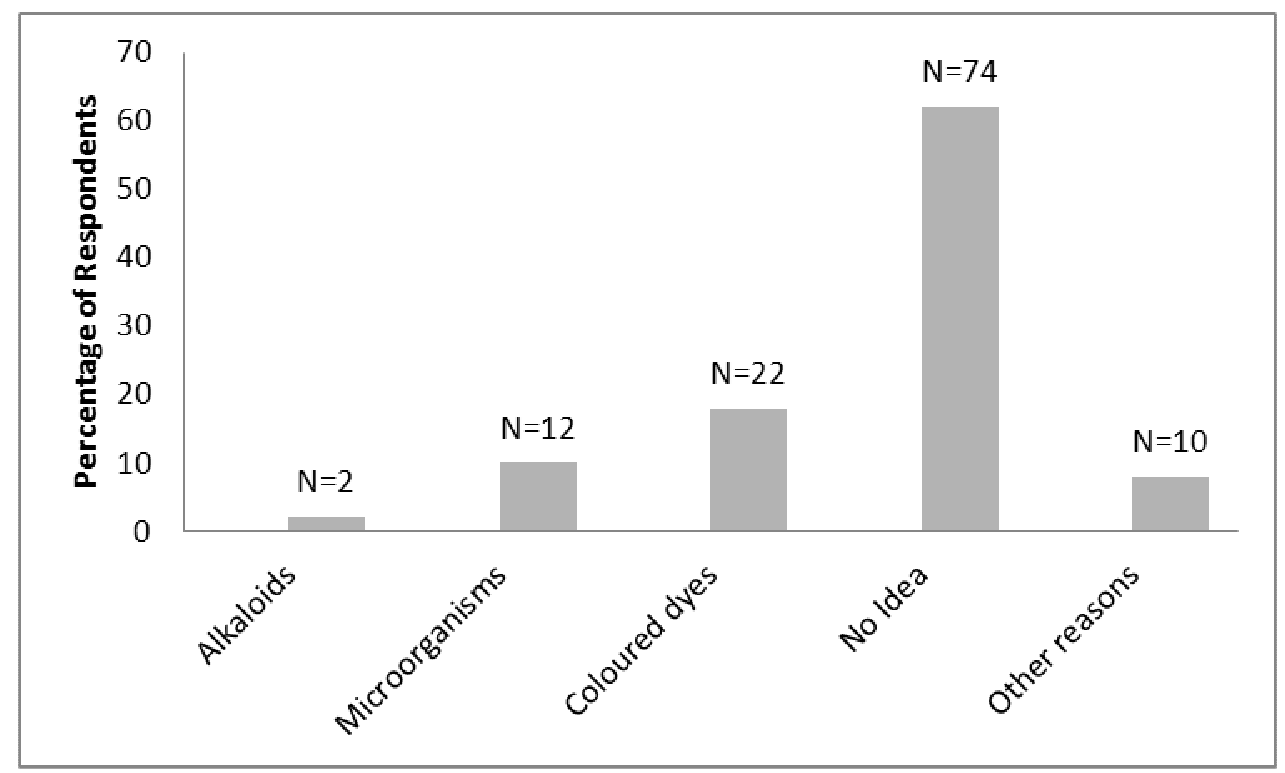

Figure 4: Possible "migrants" from leaves into cornmeal.

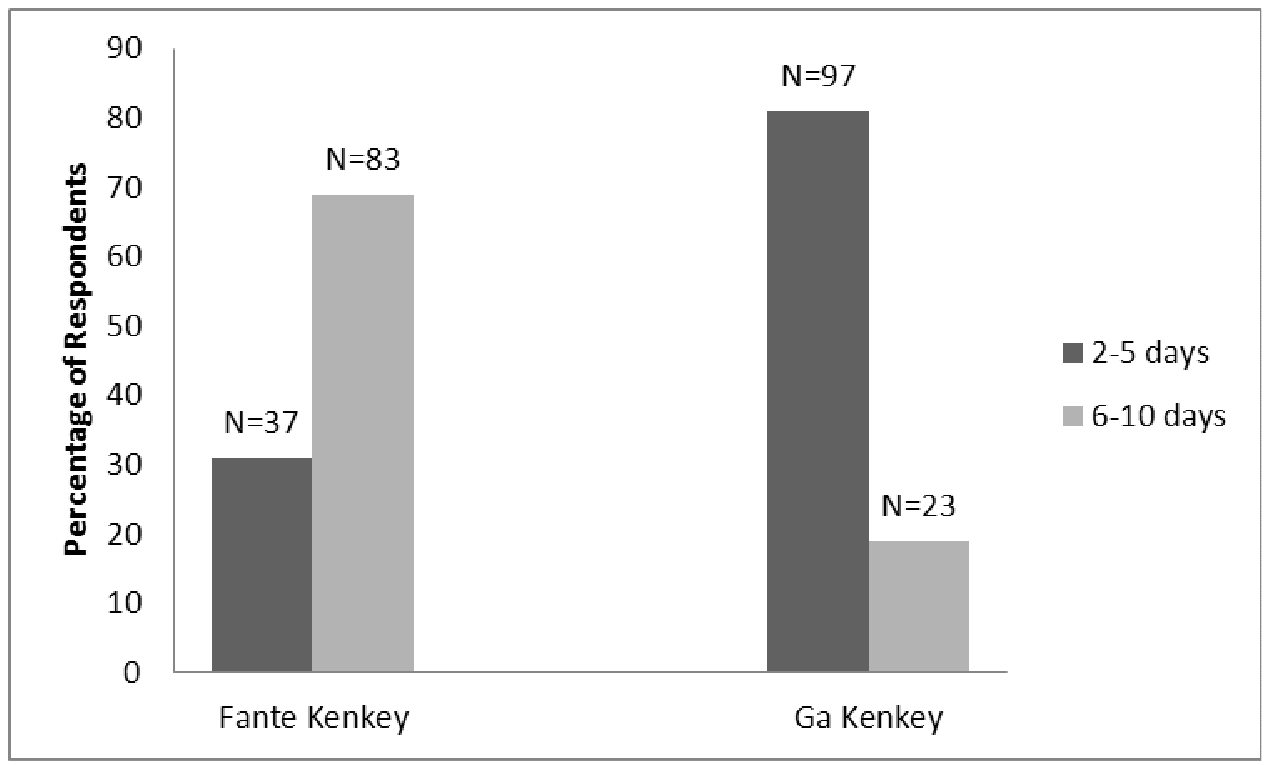

Figure 5: Consumer perceived shelf-lives of Fante and Ga Kenkeys. 


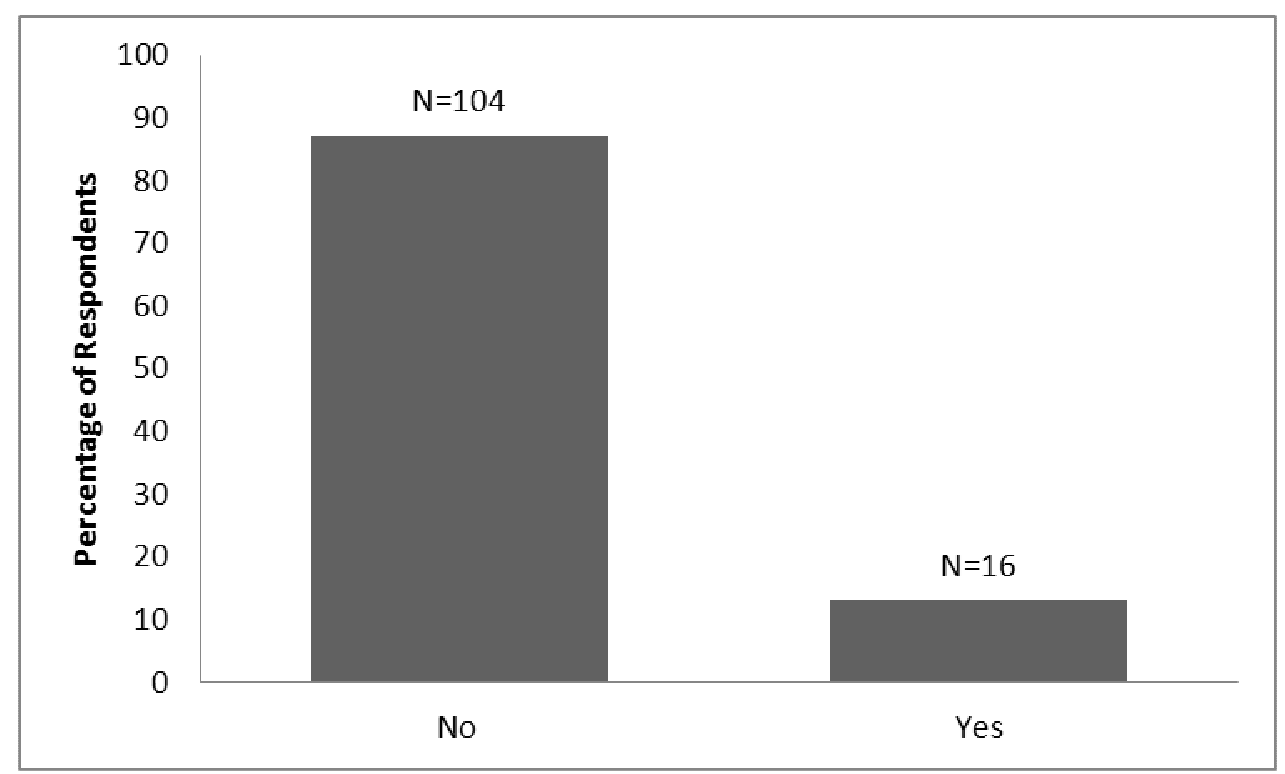

Figure 6: Use of alternative packaging material for cornmeal products.

Table 1: Available cornmeals and leaves used for food packaging.

\begin{tabular}{|c|c|c|c|c|c|}
\hline Product & \multicolumn{2}{|c|}{$\begin{array}{c}\text { Leaves for Wrapping } \\
\text { (Name) } \\
\text { Local } \\
\text { Scientific }\end{array}$} & $\begin{array}{l}\text { Medicinal Uses of } \\
\text { Leaves }\end{array}$ & Type & Remarks \\
\hline $\begin{array}{l}\text { Fante } \\
\text { kenkey } \\
(\text { Ntaw) }\end{array}$ & $\begin{array}{l}\text { Dried } \\
\text { Plantain, } \\
\text { Brodei } \\
\text { habai or } \\
\text { Awurede } \\
\text { (Akans) }\end{array}$ & $\begin{array}{c}\text { Musa } \\
\text { paradisiaca }\end{array}$ & $\begin{array}{c}\text { Anticancer, } \\
\text { hepatoprotection, } \\
\text { anti-helmintic, and } \\
\text { antimicrobial }\end{array}$ & $\begin{array}{c}\text { Cooked, } \\
\text { fermented } \\
\text { maize dough. }\end{array}$ & $\begin{array}{l}\text { Wrapped in } \\
\text { dried musa } \\
\text { paradisiaca } \\
\text { leaves before } \\
\text { cooking }\end{array}$ \\
\hline $\begin{array}{l}\text { Fante } \\
\text { Kenkey } \\
\text { (Dokon Pa) }\end{array}$ & $\begin{array}{c}\text { Akoronko } \\
\text { (Fante) }\end{array}$ & $\begin{array}{c}\text { Sterculia } \\
\text { tragacanta }\end{array}$ & $\begin{array}{l}\text { Anti-diarrhea, } \\
\text { anti-dysentery, } \\
\text { anti-arthritis, anti- } \\
\text { rheumatism, anti- } \\
\text { edema, anti-gout } \\
\text { and anti-whitlow }\end{array}$ & $\begin{array}{c}\text { Cooked, } \\
\text { fermented } \\
\text { maize dough. }\end{array}$ & $\begin{array}{l}\text { Wrapped in } \\
\text { sterculia } \\
\text { tragacanta } \\
\text { leaves before } \\
\text { cooking }\end{array}$ \\
\hline Ga kenkey & $\begin{array}{l}\text { Dried Corn } \\
\text { sheath, } \\
\text { Abro habai } \\
\text { (Akans), } \\
\text { Abele Baa } \\
(\mathrm{Ga})\end{array}$ & Zea mays & $\begin{array}{l}\text { Analgesic, anti- } \\
\text { inflammatory and } \\
\text { anti- cholesterol }\end{array}$ & $\begin{array}{c}\text { Cooked, } \\
\text { fermented } \\
\text { maize dough. }\end{array}$ & $\begin{array}{c}\text { Wrapped in } \\
\text { dried zea mays } \\
\text { sheath before } \\
\text { cooking }\end{array}$ \\
\hline Fomfom & $\begin{array}{l}\text { Fresh } \\
\text { Plantain, } \\
\text { Brodei } \\
\text { habai or }\end{array}$ & $\begin{array}{c}\text { Musa } \\
\text { paradisiaca }\end{array}$ & $\begin{array}{c}\text { Anticancer, } \\
\text { hepatoprotection, } \\
\text { anti-helmintic, and } \\
\text { antimicrobial }\end{array}$ & $\begin{array}{c}\text { Cooked, } \\
\text { fermented } \\
\text { dehulled } \\
\text { maize dough. }\end{array}$ & $\begin{array}{l}\text { Wrapped in } \\
\text { toasted fresh } \\
\text { musa } \\
\text { paradisiaca }\end{array}$ \\
\hline
\end{tabular}




\begin{tabular}{|c|c|c|c|c|c|}
\hline & $\begin{array}{l}\text { Awurede } \\
\text { (Akans) }\end{array}$ & & & & $\begin{array}{l}\text { leaves after } \\
\text { cooking }\end{array}$ \\
\hline Nsiho & $\begin{array}{c}\text { Fresh } \\
\text { Plantain, } \\
\text { Brodei } \\
\text { habai or } \\
\text { Awurede } \\
\text { (Akans) }\end{array}$ & $\begin{array}{c}\text { Musa } \\
\text { paradisiaca }\end{array}$ & $\begin{array}{c}\text { Anticancer, } \\
\text { hepatoprotection, } \\
\text { anti-helmintic, and } \\
\text { antimicrobial }\end{array}$ & $\begin{array}{c}\text { Cooked, } \\
\text { fermented } \\
\text { dehusked } \\
\text { maize dough. }\end{array}$ & $\begin{array}{l}\text { Wrapped in } \\
\text { fresh musa } \\
\text { paradisiaca } \\
\text { leaves before } \\
\text { cooking }\end{array}$ \\
\hline Estew & $\begin{array}{c}\text { Dried } \\
\text { Plantain, } \\
\text { Brodei } \\
\text { habai or } \\
\text { Awurede } \\
\text { (Akans) }\end{array}$ & $\begin{array}{c}\text { Musa } \\
\text { paradisiaca }\end{array}$ & $\begin{array}{c}\text { Anticancer, } \\
\text { hepatoprotection, } \\
\text { anti-helmintic, and } \\
\text { antimicrobial }\end{array}$ & $\begin{array}{c}\text { Cooked, } \\
\text { fermented } \\
\text { maize dough. }\end{array}$ & $\begin{array}{l}\text { Wrapped in } \\
\text { dried musa } \\
\text { paradisiaca } \\
\text { leaves after } \\
\text { cooking }\end{array}$ \\
\hline Nkyekyera & $\begin{array}{l}\text { Dry Corn } \\
\text { sheath, } \\
\text { Abro habai } \\
\text { (Akans), } \\
\text { Abele Baa } \\
\text { (Ga) }\end{array}$ & Zea mays & $\begin{array}{l}\text { Analgesic, anti- } \\
\text { inflammatory and } \\
\text { anti- cholesterol }\end{array}$ & $\begin{array}{c}\text { Cooked, } \\
\text { soaked and } \\
\text { polished maize } \\
\text { with } \\
\text { groundnut }\end{array}$ & $\begin{array}{l}\text { Wrapped in } \\
\text { dried zea mays } \\
\text { sheath before } \\
\text { cooking }\end{array}$ \\
\hline Kaafa & Ntentrema & $\begin{array}{l}\text { Thespesia } \\
\text { populnea }\end{array}$ & $\begin{array}{l}\text { Anti-diabetic } \\
\text { activity }\end{array}$ & $\begin{array}{l}\text { Light maize } \\
\text { product for } \\
\text { invalids. }\end{array}$ & $\begin{array}{l}\text { Wrapped in } \\
\text { thespesia } \\
\text { populnea } \\
\text { leaves after } \\
\text { cooking }\end{array}$ \\
\hline Aboloo & Ntentrema & $\begin{array}{l}\text { Thespesia } \\
\text { populnea }\end{array}$ & $\begin{array}{c}\text { Anti-diabetic } \\
\text { activity }\end{array}$ & $\begin{array}{c}\text { Baked or } \\
\text { steamed maize } \\
\text { dough. }\end{array}$ & $\begin{array}{l}\text { Baked or } \\
\text { steamed in } \\
\text { thespesia } \\
\text { populnea } \\
\text { leaves }\end{array}$ \\
\hline $\begin{array}{l}\text { Sugared } \\
\text { Kenkey }\end{array}$ & $\begin{array}{l}\text { Dried } \\
\text { Plantain, } \\
\text { Brodei } \\
\text { habai or } \\
\text { Awurede } \\
\text { (Akans) }\end{array}$ & $\begin{array}{c}\text { Musa } \\
\text { paradisiaca }\end{array}$ & $\begin{array}{c}\text { Anticancer, } \\
\text { hepatoprotection, } \\
\text { anthelmintic, and } \\
\text { antimicrobial }\end{array}$ & $\begin{array}{l}\text { Cooked, } \\
\text { unfermented } \\
\text { maize dough } \\
\text { with sugar. }\end{array}$ & $\begin{array}{l}\text { Wrapped in } \\
\text { dried musa } \\
\text { paradisiaca } \\
\text { leaves before } \\
\text { cooking. }\end{array}$ \\
\hline Osinographic & Aworom & $\begin{array}{c}\text { Marantochloa } \\
\text { cuspidata }\end{array}$ & Anti-diarrhea & $\begin{array}{l}\text { Cooked, } \\
\text { unfermented } \\
\text { maize dough } \\
\text { with sugar. }\end{array}$ & $\begin{array}{l}\text { Wrapped in } \\
\text { marantochloa } \\
\text { cuspidata } \\
\text { leaves before } \\
\text { cooking. }\end{array}$ \\
\hline
\end{tabular}


Table 2: Consumer demand for leaf-packaged corn-meal.

\begin{tabular}{lcccc}
\hline Name of Product & \multicolumn{3}{c}{$\begin{array}{c}\text { Consumer Demand } \\
(\boldsymbol{\%})\end{array}$} & Total (\%) \\
\hline & High & Average & Low \\
FanteKenkey & 86 & 14 & & 100 \\
GaKenkey & 74 & 26 & 20 & 100 \\
Kaafa & & 80 & 50 & 100 \\
Sugared Kenkey & 50 & & 100 \\
\hline
\end{tabular}

Table 3: Sociodemographic measures of leaves packaged products producers in the Kumasi metropolis $(\mathrm{N}=70)$.

\begin{tabular}{|c|c|c|}
\hline Sociodemographic & Frequency & Percentage \\
\hline \multicolumn{3}{|l|}{ Sex: } \\
\hline Male & 0 & 0 \\
\hline Female & 70 & 100 \\
\hline \multicolumn{3}{|l|}{ Age: } \\
\hline $15-25$ years & 1 & 1 \\
\hline $26-35$ years & 5 & 7 \\
\hline $36-45$ years & 25 & 36 \\
\hline Above 46 years & 39 & 56 \\
\hline \multicolumn{3}{|l|}{ Marital Status: } \\
\hline Single & 3 & 10 \\
\hline Married & 60 & 86 \\
\hline Divorced & 7 & 4 \\
\hline \multicolumn{3}{|l|}{ Educational Background } \\
\hline No Formal Education & 35 & 50 \\
\hline Primary/Middle School & 31 & 44 \\
\hline Secondary & 3 & 4 \\
\hline Technical/Vocational & 1 & 2 \\
\hline Tertiary & 0 & 0 \\
\hline \multicolumn{3}{|l|}{ Years of Experience } \\
\hline $1-5$ years & 4 & 6 \\
\hline $6-10$ years & 15 & 22 \\
\hline $11-15$ years & 11 & 16 \\
\hline $16-20$ years & 13 & 19 \\
\hline Over 21 years & 26 & 38 \\
\hline \multicolumn{3}{|l|}{ Name of Product Processed } \\
\hline Fante Kenkey & 29 & 41 \\
\hline Ga Kenkey & 27 & 39 \\
\hline Kaafa & 5 & 7 \\
\hline Nkyekyera & 5 & 7 \\
\hline Others & 4 & 6 \\
\hline
\end{tabular}


Table 4: Sociodemographic measures of leaves packaged product sellers in the Kumasi metropolis $(\mathrm{N}=40)$.

\begin{tabular}{lcc}
\hline Sociodemographic & Frequency & Percentage \\
\hline Sex: & 0 & 0 \\
$\quad$ Male & 40 & 100 \\
$\quad$ Female & & \\
Age: & 10 & 25 \\
15-25 years & 15 & 38 \\
26-35 years & 9 & 22 \\
36-45 years & 6 & 15 \\
$\quad$ Above 46 years & & \\
Marital Status: & 11 & 27 \\
$\quad$ Single & 25 & 63 \\
$\quad$ Married & 4 & 10 \\
$\quad$ Divorced & & \\
Educational Background & 17 & 43 \\
$\quad$ No Formal Education & 15 & 37 \\
$\quad$ Primary/Middle School & 4 & 10 \\
$\quad$ Secondary & 4 & 10 \\
$\quad$ Technical/Vocational & 0 & 0 \\
Tertiary & & \\
Number of Balls Purchased per Day & 1 & 3 \\
$\quad$ 10-50 balls & 12 & 30 \\
51-100 balls & 11 & 28 \\
10-150 balls & 16 & 40 \\
$\quad$ Above 150 balls & & \\
Name of Product Processed & 21 & 53 \\
Fante Kenkey & 9 & 23 \\
Ga Kenkey & 2 & 5 \\
Kaafa & 3 & \\
Nkyekyera & 5 & \\
Others & & \\
\hline
\end{tabular}

Table 5: Sociodemographic measures of consumers in Kumasi metropolis ( $\mathrm{N}=120)$.

\begin{tabular}{|c|c|c|}
\hline Sociodemographic & Frequency & Percentage \\
\hline \multicolumn{3}{|l|}{ Sex: } \\
\hline Male & 91 & 76 \\
\hline Female & 29 & 24 \\
\hline \multicolumn{3}{|l|}{ Age: } \\
\hline $15-25$ years & 97 & 81 \\
\hline $26-35$ years & 17 & 14 \\
\hline $36-45$ years & 5 & 3 \\
\hline Above 46 years & 1 & 2 \\
\hline \multicolumn{3}{|l|}{ Marital Status: } \\
\hline Single & 102 & 85 \\
\hline & & \\
\hline
\end{tabular}




\begin{tabular}{lcc}
\hline Married & 16 & 13 \\
Divorced & 2 & 2 \\
Educational Background & & \\
No Formal Education & 4 & 3 \\
Primary/Middle School & 10 & 8 \\
Secondary & 7 & 6 \\
Technical/Vocational & 0 & 0 \\
Tertiary & 99 & 83 \\
Years of Leaf-packaged Product Consumption & & \\
2-10 years & 31 & 26 \\
11-20 years & 55 & 46 \\
21-30 years & 28 & 23 \\
Over 31 years & 6 & 5 \\
Leaf-packaged Product Mostly Eaten & & \\
Fante Kenkey & 55 & 46 \\
Ga Kenkey & 60 & 50 \\
Others & 5 & 4 \\
Product Consumption Rate & & \\
Once a week & 15 & 13 \\
About thrice a week & 67 & 56 \\
About five times a week & 30 & 7 \\
Almost everyday & 8 & \\
Number of Balls Taken & & 34 \\
1 & 41 & 66 \\
2 & 79 & \\
\hline
\end{tabular}

Table 6: Producers', sellers' and consumers' concerns.

\begin{tabular}{lccc}
\hline & Producers (\%) & Sellers (\%) & Consumers (\%) \\
\hline Unhygienic & 5 & 0 & 7 \\
Short Shelf Life & 6 & 20 & 18 \\
Hardens Easily & 11 & 47 & 60 \\
No Apparent Concern & 59 & 25 & 10 \\
Other Reasons & 19 & 8 & 5 \\
\hline
\end{tabular}

\section{DISCUSSION}

Women of all ages play important roles in the production and selling of leavespackaged cornmeal as demonstrated by the observation that all producers and sellers participants were women. Unlike selling, production requires some form of the on-thejob training and experience and that time lag possibly explains why producers were mostly middle aged while sellers were at least 10 years younger. Since leaves-packaged cornmeal industry is traditional, little or no formal education is required for engagement in the dual activities of production and selling. Hence most producers and sellers interviewed have little or no formal education. Producers have traditionally engaged members of their immediate or extended family as helping hands in the small scale production of leavespackaged cornmeals (Essuman, 1990). While some producers sell directly to consumers, others utilize the services of family members. 
Sellers and producers often live in the same community or belong to the same ethnic group. Consequently, production and selling of leaves-packaged cornmeals are anecdotally considered subsistence activities that strengthen cultural and family bonds (Hicks, 2002).

The eclectic mix of all ages, gender and socioeconomic groups that comprise consumers of leaf-packaged cornmeals is in line with its mainstream appeal. By far Kenkey (Fante and Ga) are the most preferred product, accounting for $80 \%$ of all leavespackaged cornmeals processed by producers, $76 \%$ of all products offered by sellers and $96 \%$ of all purchases by consumers. Once considered ethnic food, Kenkey is now eaten by nearly all Ghanaians with young (25 years or younger) highly educated (tertiary institution trained) single males relying mostly on the Ga variety for their dietary calories. The eating of Kenkey and the other leavespackaged cornmeals is not influenced by ones economic and educational status as well as ones geographical location. Kenkey's appeal has gone international as it is prepared and packaged in leaves as done in Ghana and sold in supermarkets within countries that have substantial number of West Africans Diasporaens (Delisle et al., 2010). Kenkey is usually served with deep fried or grilled fish and freshly ground sauce of onions, tomatoes, and pepper with salt to taste together with black fried pepper. It could also be mashed with water into slurry and taken chilled with sugar and milk added to taste.

Ultimately, the continued success of any packaging material depends on its cost relative to its properties and its performance. Leaves are readily available and relatively inexpensive. Producers agree that the availability of leaves at relatively low cost is a contributing factor to its prevalence as packaging material for cornmeals. As a result of low packaging cost, producers can still maintain profitability by selling the cornmeals at affordably low prices. Consequently, leaves-packaged corn meals are one of the most inexpensive primary sources of dietary calories for most Ghanaians.

As packaging materials, the strength, barrier properties and the impermeability of musa paradisiacal, zea mays, and thespesia populnea leaves are low compared to that of plastics. Nonetheless, leaves serve the primary functions of any packaging material by providing containment, protection and preservation of the cornmeal. Each of the leaves packages keep the cornmeal product encased in good condition for its anticipated shelf life. The leaves prevent destruction of the corn meal by microbial or insect attack and preserve the quality and the nutritive value of the packaged foods for about 2-10 days without refrigeration and without any added synthetic preservatives (Essuman, 1990). Physically, the leaves help in maintaining the moisture content, preventing recontamination and consequent degradation or spoilage of the food once cooked as demonstrated by the relatively high moisture content and longer shelf life of Fante Kenkey. It is likely that leaves act as active packaging materials through the migration of some biologically active phytoconstituents, including oxygen scavengers and antimicrobials that possess the capacity to inhibit oxidative and microbial growth processes that adversely affect food qualities such as flavour, colour and reduced nutritional value. The relatively low shelf life of $\mathrm{Ga}$ Kenkey is partly attributable to the physical separation between adjoining zea mays sheaths covering. The created physical gaps likely permit moisture loss and provide easy microbial access to the cornmeal.

There is unanimous acclaim from all producers that musa paradisiaca leaves, zea mays husk, and thespesia populnea leaves are non-toxic and thus ingestion of phytochemicals having deleterious effect on the body by consumers is rare. While no scientific evidence supports this safety record, it is noted that no association has ever been observed or reported between ingestion of leaves-packaged cornmeal and any health hazard. Unlike plastics, that leach xenotoxic 
substances including styrene and bisphenol A and other endocrine disruptor chemicals into food (Halden, 2010; Muncke, 2009; Munche, 2010), the leaves of musa paradisciaca, sterculia tragacanta and marantochloa cuspidate, zea mays husk and thespesia populnea infuse the packed food with phytochemicals that give the product a distinctive aroma, taste, and colour. The infusion of the cornmeals with medicinal phytonutrients is the preferential reason given by producers for the prevalence of leaves as packaging material for cornmeals.

While the leaves are of more interest in this study for its packaging than for its phytochemistry, it is noted that anecdotal evidence supports the assertion by $61 \%$ of the producers that the leaves adds medicinal value to the packaged cornmeal. The leaves of musa paradisiaca contain alkaloids, tannins, and a broad class of polyphenolic phytochemicals that exhibit chemopreventive anticancer properties in humans (Milder et al., 2005); hepatoprotection in rats (Dikshit et al., 2011); anthelmintic activity against nematodes in livestock (Hussein et al., 2010) and antimicrobial activity against pathogenic Staphylococcus and Pseudomonas species in vitro (Alisi et al., 2008; Ahmad and Beg, 2001). Phytochemicals present in the husk of zea mays that include polyphenols, anthocyanins, lutein and zeaxanthins, tannins have been shown to exhibit analgesic and antiinflammatory effects in male Wistar rats (Owoyele et al., 2010). Zea mays husk oil is reported to lower plasma LDL cholesterol concentrations via alteration in hepatic cholesterol metabolism in guinea pigs (Ramjiganeshet et al., 2000). The phytoconstituents of sterculiatragacantha include alkaloids, flavonoids, tannins, glycosides and saponins and ethnomedicinal practices throughout West Africa that depends on the bioactivity of these phytochemicals include the treatment of diarrhea, dysentery, arthritis, rheumatism, edema, gout and whitlow (Udegbunam et al., 2011).

Phytochemicals present in the leaves of thespesia populnea including lupenol, lupenone, b-sistosterol, acacetin, quercetin, vanillic, syringic, melilotic, and ferulic acids and the general family of tannins, flavonoids and triterpenoids exhibit antidiabetic activity against streptozotocin-induced diabetic rats (Parthasarathy et al., 2009). Marantochloa cuspidate is used in West African ethnomedicine as anti-diarrhea medication (Abbiw, 1990). Interestingly, the residual liquid from boiled $\mathrm{Ga}$ Kenkey is used in Ghanaian ethnomedicine for the treatment of fever and diarrhea (Yartey at al., 1993). Some participants asserted that the potential medicinal effects will be lost if a switch from musa paradisiaca leaves and corn-sheath to plastic packaging is made for cornmeals.

It is unknown whether the concentration and the bioavailability of the phytochemicals in a cornmeal diet are sufficient to impart any medicinal effects to consumers. Unwittingly, leaves phytochemicals that leach into the cornmeal become dietary constituents with potential disease chemopreventive and chemotherapeutic properties. It will be interesting to characterize the potential migratory extractable naturally occurring volatile and non-volatile compounds from the indigenous leaves used as ready-to-eat cornmeal packaging material and to examine the potential health benefits or otherwise of the phytochemical constituents of the indigenous leaves packages to consumers. Potential markets for the flavours exist if they could be extracted or synthesized as food additives.

At its most sophisticated, leaves, as packaging material, provides two additional functions: convenience and selling. Consumers' quest for convenience is partly satisfied by the packaging and by the readyto-eat attribute that implies less time spent on kitchen and household cooking chores. Consumers need only to peel off the leaves and the cornmeal is ready to eat. Perhaps its convenience contributes to the observation that most Ghanaian consumers eat at least 144 balls of Ga or Fante Kenkey per year either away from home or in a home setting. 
That the leaves packages still sell cornmeal suggests no apparent change in consumer taste and preferences for thousands of years. In spite of the perception of low quality that leaves packaging convey, there is still high consumer acceptability and great demand for it. In fact leaves-packaged cornmeals have not only survived but also flourished in modern times in Ghana and other parts of the world. Even in modern era where food is frequently packaged in attentiongrabbing materials and the only difference between competitive brands is in the sophistication of the packaging (PetersTexeira and Badrie, 2005; Venter et al., 2011), leaves-packaged cornmeal has continued to sustain consumer respectability without the advantages of eye-catching or attentiongrabbing graphics. A new trend has, however, emerged where few producers wrap the cornmeal in polyethylene bags before leaf packaging is applied. The general consumer receptibility to these changes is unknown and it will be interesting to study this changing dynamics. Within this context, questions that demand answers include: to what extent is the migration of plasticizers and other degradative products from the plastic wrappings during cooking into the food likely to affect the health of consumers? Do the plastic that is used as the primary wrappings of these indigenous foods adsorb nonvolatile and/or nonpolar phytoconstituents such as volatile flavours and aromas from the foods or leaf wrappings?

A drawback of leaves as packaging material for cornmeal products is the lack of display of nutritional content information on the product. The packages are bland with no display of name, no nutritional labeling, and no instructions for consumer use and storage (Essuman, 1990; Dimura and Skuras, 2005; Nanacarrow et al., 1998). But as one of the primary sources of dietary calories, consumers have identified with the cornmeals as products rich in low-resistant starchy carbohydrates (Amoa and Muller, 1976). Consumers have also learned, via experience, about the type of cornmeal product that is encased in each specific leaves package.

The consideration that leaves are environmentally friendlier because they are easier to biodegrade than alternative packaging materials including plastics is perhaps blunted by its perceived sub-standard hygiene (Adejumo and Ola, 2008) leading to low shelf lives. Notwithstanding this disadvantage, an overwhelming majority of consumers declined a change to alternative packaging materials for ready-to-eat cornmeal leading to the suggestion that perhaps entrenchment of cultural dietary habits might play a role in the prevalence of leaves as packaging material. Dietary habits, especially the deep-rooted cultural ones, are sometimes impervious to change (Walle et al., 1997). Whether the continuing use of leaves as packaging materials for ready-to-eat cornmeals in Ghana is partly attributable to cultural reticence to change or to additional alternative reasons is yet to be delineated by further studies.

\section{Conclusion}

Food industry has made significant strides in packaging innovations driven primarily by consumer demands and preferences. But the historical use of leaves to package ready-to-eat cornmeal products in Ghana has yet to experience significant changes. The leaves of musa paradisciaca, sterculia tragacanta, marantochloa cuspidata, zea mays husks and thespesia populnea are non-toxic, have medicinal qualities, are readily available at relatively low cost and are environmentally friendlier. However, the leaves packaged cornmeals have short shelflives and are hygienically sub-standard. Nevertheless, consumers still prefer the leaves of musa paradisciaca, sterculia tragacanta, marantochloa cuspidate, zea mays husks and thespesia populnea as packaging material for ready-to-eat cornmeal.

\section{REFERENCES}

Abbiw J. 1990. Conservation and cultivation of medicinal plants in 
Ghana. http://www.unep-cmcapps.org/species/plants/ghana/pdfs/he rbarium.pdf.

Adejumo BA, Ola FA. 2008. The appraisal of local food packaging materials in Nigeria. Continental J. Engineering Sciences, 3(1): 13-20.

Ahmad I, Beg A. 2001. Antimicrobial and phytochemical studies on 45 Indian medicinal plants against multi-drug resistant human pathogens. Journal of Ethnopharmacology, 74(1): 113-123.

Alisi CS, Nwanyanwu CE, Akujobi CO, Ibegbulem CO. 2008. Inhibition of dehydrogenase activity in pathogenic bacteria isolates by aqueous extracts of Musa paradisiaca (Var Sapientum). African Journal of Biotechnology, 7(12): 1821-1825.

Amoa B, Muller HG. 1976. Studies on Kenkey with particular reference to calcium and phytic acid. Cereal Chemistry, 53(3): 365-375.

Brody AL, Bugusu B, Han JH, Sand CK, McHugh TH. 2008. Scientific status summary. Innovative food packaging solutions. J Food Sci., 73(8): R107-R116.

Dainelli D, Gontard N, Spyropoulos D, Zondervan-van den Beuken Eand Tobback P. 2008. Active and intelligent food packaging: legal aspects and safety concerns. Trends in Food Science and Technology, 19(1): S103-S112.

Delisle H. 2010. Findings on dietary patterns in different groups of African origin undergoing nutrition transition. Appl. Physiol. Nutr. Metab., 35(2): 224-228.

Dikshit P, Tyagi MK, Shukla K, Sharma S, Gambhir JK, Shukla R. 2011. Hepatoprotective effect of stem of Musa sapientum Linn in rats intoxicated with carbon tetrachloride. Annals of Hepatology, 10(3): 333-339.

Dimura E, Skuras D. 2005. Consumer demand for informative labeling of quality food and drink products: a European Union case study. Journal of Consumer Marketing, 22(2): 90-100.
Essuman KM. 1990. Local packaging of foods in Ghana. Food and Nutrition Bulletin, 12(1): 64-68

Halden RU. 2010. Plastics and health risks. Annu. Rev. Public Health, 21(31): 179194.

Hicks A. 2002. Minimum-Packaging technology for processed foodsenvironmental considerations. http:// www.journal.au.edu/au_techno/2002/oct2 002/aujt6-2_article06.pdf.

Hussain A, Khan MN, Sajid MS, Iqbal Z, Khan MK, Abbas RZ, Raza MA, Needham GR. 2010. In vitro screening of the leaves of musa paradisiacal for antihelmintic activity. The Journal of Animal and Plant Sciences, 20(1): 5-8.

Imran M, Revol-Junelles AM, Martyn A, Tehrany EA, Jacquot $M$, Linder $M$, Desobry S. 2010. Active food packaging evolution: transformation from micro- to nanotechnology. Crit. Rev. Food Sci. Nutr., 50(9): 799-821.

Milder IE, Arts IC, van de Putte B, Venema DP, Hollman PC. 2005. Lignan contents of Dutch plant foods: a database including lariciresinol, pinoresinol, secoisolariciresinol and matairesinol. $\mathrm{Br}$. J. Nutr., 93(3): 393-402.

Muncke J. 2009. Exposure to endocrine disrupting compounds via the food chain: Is packaging a relevant source. Sci Total Environ., 407(16): 4549-4559.

Muncke J. 2010. Endocrine disrupting chemicals and other substances of concern in food contact materials: An updated review of exposure, effect and risk assessment. J. Steroid Biochem. Mol. Biol., 10(94): 12-18.

Nancarrow C, Wright TL, Brace I. 1998. Gaining competitive advantage from packaging and labeling in marketing communications. British Food Journal, 100(2): 110-118.

Owoyele BV, Negedu MN, Olaniran SO, Onasanwo SA, Oguntoye SO, Sanya JO, Oyeleke SA, Ibidapo AJ, Soladoye AO. 2010. Analgesic and anti-inflammatory effects of aqueous extract of Zea mays 
Husk in male Wistar rats. J. Med. Food, 13(2): 343-347.

Parthasarathy R, Ilavarasan R, Karrunakaran CM. 2009. Antidiabetic activity of Thespesia Populnea bark and leaf extract against streptozotocin induced diabetic rats. International Journal of Pharm. Tech. Research, 1(4): 1069-1072.

Peters-Texeira A, Badrie N. 2005. Consumers' perception of food packaging in Trinidad, West Indies and its related impact on food choices. International Journal of Consumer Studies, 29(6): 508514.

Ramjiganesh T, Roy S, Nicolosi RJ, Young TL, McIntyre JC, Fernandez ML. 2000. Corn husk oil lowers plasma LDL cholesterol concentrations by decreasing cholesterol absorption and altering hepatic cholesterol metabolism in guinea pigs. J. Nutr. Biochem., 11(8): 358-366.

Rettie R, Brewer C. 2000. The verbal and visual components of package design. Journal of Product and Brand Management, 9(1): 56 - 70.

Risch SJ. 2009. Food Packaging History and Innovations. J. Agric. Food Chem., 57(18): 8089-8092.
Silayoi P, Speece M. 2007. The importance of packaging attributes: a conjoint analysis approach. European Journal of Marketing, 41(11): 1495-1517.

Udegbunam RI, Asuzu UI, Kene ROC, Udegbunam SO, Nwaehujor C. 2011. Anti-nociceptive, anti-inflammatory and anti-oxidant effects of the methanol leaf extract of Sterculiatragacantha Lindl. Journal of Pharmacology and Toxicology, 6(5): 516-524.

Venter K, van der Merwe D, de Beer H, Kempen E, Bosman M. 2011. Consumers' perceptions of food packaging: an exploratory investigation in Potchefstroom, South Africa. International Journal of Consumer Studies, 35(3): 273-281.

Walle AH. 1997. Global behaviour, unique responses:consumption within cultural frameworks. Management Decision, 35(10): 700-708.

Yartey J, Harisson EK, Brakohiapa LA, Nkrumah FK. 1993. Carbohydrate and electrolyte content of some homeavailable fluids used for oral rehydration in Ghana. J. Trop. Pediatr., 39(4): 234237. 